\title{
Protocadherin Fat 1
}

National Cancer Institute

\section{Source}

National Cancer Institute. Protocadherin Fat 1. NCI Thesaurus. Code C17492.

Protocadherin Fat 1 (4588 aa, $~ 506 \mathrm{kDa}$ ) is encoded by the human FAT1 gene. This protein is involved in both cell-cell adhesion and cellular polarization. 